\title{
Structural Changes in Vertebrae of Mice Based on Experimental Model of Rheumatoid Arthritis
}

\author{
Demid Oyuntsetseg1, Ochirpurev Munkhjargal1, Chimed Mandalshaihan1, \\ Avirmed Amgalanbaatar ${ }^{2}$, Enebish Sundui' ${ }^{2}$, Hany Wahila1, Amgalanbaatar Dorjkhuu² \\ ${ }^{1}$ Department of Professional Science, Gobi-Altai School of Mongolian National University of Medical Sciences, \\ Gobi-Altai, Mongolia \\ ${ }^{2}$ Morphology Department, Bio-Medicine and Pharmacology School of Mongolian National University of Medical Sciences, \\ Ulaanbaatar, Mongolia \\ Email: Oyuntsetseg.d@mnums.edu.mn,munkhjargal@mnums.edu.mn, enebish@mnums.edu.mn, \\ awahila@umn.edu, avirmed.a@mnums.edu.mn,mandalshaihan@mnums.edu.mn
}

How to cite this paper: Oyuntsetseg, D., Munkhjargal, O., Mandalshaihan, C., Amgalanbaatar, A., Sundui, E., Wahila, H. and Dorjkhuu, A. (2018) Structural Changes in Vertebrae of Mice Based on Experimental Model of Rheumatoid Arthritis. Open Journal of Applied Sciences, 8, 1-11. https://doi.org/10.4236/ojapps.2018.81001

Received: November 1, 2017

Accepted: January 8, 2018

Published: January 11, 2018

Copyright ( $) 2018$ by authors and Scientific Research Publishing Inc. This work is licensed under the Creative Commons Attribution International License (CC BY 4.0).

http://creativecommons.org/licenses/by/4.0/

\section{(c) (i) Open Access}

\begin{abstract}
Studies have shown that autoimmunity causes pathogenesis of more than 100 diseases. Among these diseases, approximately 1-2\% of the world's population has rheumatoid arthritis disease, which is a chronic disease that affects 45 out of every 3000 people who have autoimmune diseases. The aim of this research is to address the possible treatment of rheumatoid arthritis disease by comparing and contrasting the effectiveness and influence that treatments have on treating the disease. This study will be conducted by inducing the following treatments: ibuprofen and Boigor-10 on model animal subjects (mice) to determine the outcomes of the treatment. We will assess the outcomes by investigate the structural changes on vertebrae and joints of these subjects and the clinical manifestation score of each treatment. We hypothesize that these treatments will improve the treatment of rheumatoid arthritis disease. Furthermore, we hope that this research contributes to further understanding autoimmune disease and promotes proper treatment of the disease.
\end{abstract}

\section{Keywords}

Arthritis, Joint, Experiment, Pannus, Vertebra, Histology

\section{Background}

Autoimmune diseases refer to problems with the acquired immune systems 
reactions. In an autoimmune reaction, antibodies and immune cells accidently target the bodies' healthy tissues, which signaling the body to attack them. Researchers reported that there are more than 80 illnesses caused by autoimmunity [1]. An autoimmune disease affects approximately $8 \%$ of the world population, $78 \%$ of whom are women [2]. Studies have shown that autoimmunity causes pathogenesis of more than 100 diseases. Approximately 1-2\% of the world's population has rheumatoid arthritis and affects 45 out of every 3000 people who have autoimmune diseases. Although there are many diseases that cause chronic arthritis, rheumatoid arthritis (RA) is a chronic systemic disease, which damages the connective tissues irreversibly, gradually leading to a loss of ability to work and causing disability. This terminal illness requires permanent treatment which is highly expensive [3] [4].

\section{Aim}

To investigate the therapeutic influence of ibuprofen and Boigor-10 on experimentally induced mice with rheumatoid arthritis (RA).

\section{Objectives}

1) To induce RA in animal model and determine the structural changes on vertebrae of the mice based on the clinical findings and joint microstructural test.

2) To investigate the changes on vertebrae and joints in experimentally induced RA animals after treatment of Ibuprofen and Boigor-10.

\section{Methodology}

This experiment includes 60 mice bought from the Training and Industrial Center of Traditional Medicine who are 6 - 8 weeks old. Parts of this study, which were conducted on human organs, were carried out at The National Center of Coroner's Investigation, National Center for Maternal and Child Health, Maternity Hospital I, II, \& III, Ulaanbaatar Songdo Hospital, and Anatomical Department of Mongolian National University of Medical Science (MNUMS).

- 60 mice in the study were divided into three groups and the study was done for duration of 60 days.

- Group 1: Control group with induced arthritis.

- Group 2: Group who used Boigor-10 medication.

- Group3: Group who used Ibuprofen medication.

\section{1) Histology test or biopsy}

Sixty mice in the study were eliminated and the vertebral column was surgically removed. The biopsy test was performed using Light Microscope MBC-2, at $4 \times 10,10 \times 10,20 \times 10$, and $40 \times 1$ magnification.

The following steps were scheduled:

- Fixation: fixed in $10 \%$ neutralized formalin solution for 48 hours.

- Bone decalcification: The first method of nitric acid was employed to decalcify the bones.

- Block preparation method: Tissue-Tek VIP 5 Jr Automatic transmission ap- 
paratus was used. Dehydration, lucidification, Pouring Paraffin method, Mayer's hematoxylin-eosin staining methods were employed.

\section{2) Collagen induced arthritis}

We carried out our experimental study according to the collagen-induced RA protocols of David D. Brand, Kary A. Latham, Edward F. Rosloniec [5] [6] [7] Collagen is a fibrous protein that, at normal physiological conditions, is insoluble. Consequently, we used diluted acetic acid to keep CII in solution for use in the CIA model (in order to make solution of $10 \mathrm{~mm}$ diluted acetic acid, we added $1 \mathrm{ml}$ cold acetic acid into $1739 \mathrm{ml}$ distilled water and mixed for $5 \mathrm{~min}$ ). $2.5 \mathrm{ml}$ of the solution was also used for solubilizing the collagen II.

\section{3) Solubilizing collagen II}

We added $5 \mathrm{mg}$ collagen II into a $2.5 \mathrm{ml}$-diluted solution of acetic acid (2 - 4 $\mathrm{mg}$ dilute acetic acid/ml collagen).

Preparation of emulsion:

- Added $2.5 \mathrm{ml}$ diluted collagen II into $2.5 \mathrm{ml}$ solution of Complete Freund's Adjuvant (CFA).

- Solubilized collagen II and CFA were mixed with a ratio of $1: 1$, kept the lid tightly closed and dipped into the ice every 30 seconds. When a drop from the emulsion was put into water, the emulsion didn't scatter on water surface. This verified that the emulsion formed was stable.

\section{4) Immunization of mice}

Emulsified collagen II was injected on a carefully chosen tissue site at about 1 - 2 $\mathrm{cm}$ distal from the base of the tail. The depth of the needle was $0.5 \mathrm{~cm}$ and $50 \mu \mathrm{l}$ volume of the EC II was slowly injected intradermallyin every mouse.

After immunization we evaluated the incidence of arthritis.

The following is a scoring of Arthritis severity (individually):

- Score 0-Normal (no evidence of erythema and swelling).

- Score 1-Mild inflammation (Erythema and mild swelling) confined to the tarsals or ankle joint.

- Score 2-Inflammation from mild to average (Erythema and mild swelling) extending from the ankle to the tarsals.

- Score 3-From the intermediate to severe inflammation (Erythema and moderate swelling) extending from the ankle to metatarsal joints.

- Score 4-Severe inflammation (Erythema and severe swelling) encompass the ankle, foot, and digits, or ankylosis of the limb.

\section{5) Boigor-10 influence on collagen induced RA inflammation}

Sixty mice in the study were divided into three groups: The control group (Group I), Ibuprofen group (Group II), and Boigor-10 group (Group III). Distilled water was given orally to Group I, $17 \mathrm{mg} / \mathrm{kg}$ of Ibuprofen for Group II, and Boigor-10 for Group III (36 mg/kg) respectively, using the arthritis severity score between 0 - 4 .

\section{6) Determining the toxic effects of Boigor-10}

This experiment had been carried out on 20 white-headed BalB/C mice, which weighed 16 - 22 gr. We used the Prozorovski B.P. (1978) rapid method to deter- 
mine the median effective dose. The preparation was administered to the mice with the ratio of 1:1 intravenously. The median effective dose was $\mathrm{LD}_{50}=1.42$ $(1.24-1.61) \mathrm{g} / \mathrm{kg}$ and it referred to the low toxic classification of Sydorov K.G.

\section{7) The statistical processing of the outcomes}

A statistical and mathematical calculation outcome of the biopsy and protocols (body weight, arthritis severity score) during the experiment was done using SPSS-16.0. To analyze the data, the following menus were employed: Descriptive Statistics, Compare Means, Correlation, Regression and Microsoft Office Excel, Adobe Photoshop CS3, References-Endnote X4 were used to create the figures respectively. The arithmetic mean and its errors, maximal and minimum values, and standard slop results were used on statistical analysis [8].

\section{Results}

Study of Ibuprofen and Boigor-10 treatment for experimentally induced RA and structural changes on vertebral column.

Body weight changes in control group with induced RA:

One of the most important incidents that give information on evaluating the experiments outcome is the body weight change in the control group. We weighed all the mice in the study prior to the start date of the study and since then, we weighed the mice every week. All groups of mice were weighed a total of 9 times (Table 1 and Table 2).

The arthritis severity was scored in three groups. Based on our findings, the control group and the Boigor-10 group had arthritis severity difference of $p<$ 0.001. According to the Student's criteria, the difference between the control group and Ibuprofen group was $p<0.001$, which was statistically significant. There was no statistical significance between the Boigor-10 and Ibuprofen group (Figure 1).

Table 1. Body weight comparison of control and treatment group.

\begin{tabular}{ccccc}
\hline $\mathrm{N}^{\circ}$ & Days & Control group & Boigor-10 group & Ibuprofen group \\
\cline { 3 - 5 } & & $\mathrm{M} \pm \mathrm{m}$ & $\mathrm{M} \pm \mathrm{m}$ & $\mathrm{M} \pm \mathrm{m}$ \\
\hline 1 & First day & $24.34 \pm 0.49$ & $24.25 \pm 0.51$ & $23.95 \pm 0.49$ \\
2 & 7 days & $25.11 \pm 0.48$ & $25.05 \pm 0.52$ & $25.10 \pm 0.50$ \\
3 & 14 days & $25.97 \pm 0.47$ & $25.59 \pm 0.51$ & $26.33 \pm 0.53$ \\
4 & 21 days & $26.95 \pm 0.47$ & $26.76 \pm 0.49$ & $27.56 \pm 0.48$ \\
5 & 28 days & $28.23 \pm 0.45$ & $27.57 \pm 0.47$ & $28.60 \pm 0.51$ \\
6 & 35 days & $29.45 \pm 0.45$ & $28.10 \pm 0.46$ & $29.36 \pm 0.51$ \\
7 & 42 days & $30.35 \pm 0.45$ & $28.96 \pm 0.49$ & $30.83 \pm 0.60$ \\
8 & 49 days & $31.13 \pm 0.45$ & $29.92 \pm 0.49$ & $31.34 \pm 0.62$ \\
9 & 56 days & $31.51 \pm 0.46$ & $30.68 \pm 0.50$ & $31.78 \pm 0.55$ \\
\hline
\end{tabular}




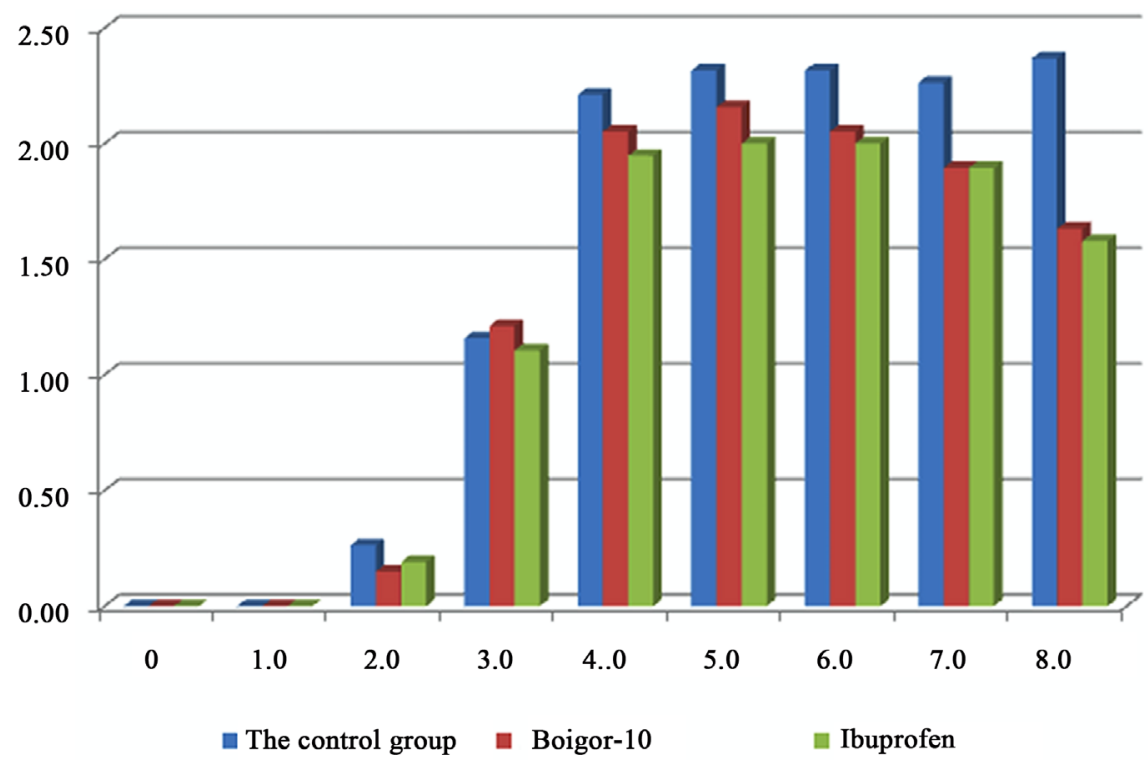

Figure 1. Comparison of arthritis severity between control group and treatment group.

Table 2. Arthritis severity comparison of control and treatment group.

\begin{tabular}{ccccc}
\hline \multirow{2}{*}{$\mathrm{N}^{\circ}$} & Week & Control group & Boigor-10 & Ibuprofen \\
\cline { 3 - 5 } & & $\mathrm{M} \pm \mathrm{m}$ & $\mathrm{M} \pm \mathrm{m}$ & $\mathrm{M} \pm \mathrm{m}$ \\
\hline 1 & First day & $0.00 \pm 0.00$ & $0.00 \pm 0.00$ & $0.00 \pm 0.00$ \\
2 & $1^{\text {st }}$ week & $0.00 \pm 0.00$ & $0.00 \pm 0.00$ & $0.00 \pm 0.00$ \\
3 & $2^{\text {nd }}$ week & $0.25 \pm 0.09$ & $0.19 \pm 0.08$ & $0.15 \pm 0.08$ \\
4 & $3^{\text {rd }}$ week & $1.16 \pm 0.13$ & $1.21 \pm 0.14$ & $1.11 \pm 0.13$ \\
5 & $4^{\text {th }}$ week & $2.21 \pm 0.09$ & $2.05 \pm 0.11$ & $1.95 \pm 0.13$ \\
6 & $5^{\text {th }}$ week & $2.32 \pm 0.11$ & $2.16 \pm 0.08$ & $2.00 \pm 0.07$ \\
7 & $6^{\text {th }}$ week & $2.32 \pm 0.12$ & $2.05 \pm 0.05$ & $2.00 \pm 0.05$ \\
8 & $7^{\text {th }}$ week & $2.26 \pm 0.10$ & $1.89 \pm 0.07$ & $1.89 \pm 0.06$ \\
9 & $8^{\text {th }}$ week & $2.37 \pm 0.10$ & $1.63 \pm 0.11$ & $1.58 \pm 0.11$ \\
\hline
\end{tabular}

\section{Microstructures Changes of Vertebral Bone (after 56 days) in Control} Group:

After 56 days of immunization, pannus accumulation was formed on every mice vertebral surface, the number of cavities in medullary ossium rubra had decreased and the cells contained in it also decreased dramatically. We found that the trabeculs had vanished and replaced with cartilage in whole.

When viewed through a microscope at $200 \times$ and $400 \times$ magnification, we found the following changes: the perichondrium of cartilage that covers the vertebral body surface became thin, and its chondroblast cells shapes were oval, the acidification of the cytoplasm had decreased dramatically, and trabeculs had vanished and were replaced with cartilage.

When viewed through a microscope at $200 \times$ and $400 \times$ magnification, the pe- 
richondrium of cartilage that covers the vertebral body surface became thin, and its chondroblast cells shapes were oval, the acidification of the cytoplasm had decreased and there was space between isogenous cells /nests/ and cells inside it (Figure 2).

\section{The Structural Changes (after 56 days) on Intervertebral Cartilaginous Disks of Control Group}

The collagen fibers of intervertebral cartilages disk become sparse in induced RA mice. Some cartilaginous disks of the vertebrae were destroyed and there was an empty space instead. When the nucleolus pulpous was cut, the cartilage disks were destroyed and had evaporated.

\section{Microstructural Changes on Vertebra after Ibuprofen Treatment}

Looking at the mice that were treated with Ibuprofen through a microscope at $100 \times$ and $200 \times$ magnification, the perichondrium of cartilage that covers the vertebral body surface and the cartilaginous layers of perichondrium lamellas had thickened. There was an intense process of forming new cartilage tissues. The chondroblast cell shapes and the acidification of the cytoplasm became normal and formed numerous isogenous/nests/cells.

Therefore, we concluded that ibuprofen treatment ceased the cartilage damage of the vertebral body surface and pannus accumulation process. It also intensified the regeneration of vertebral body and trabecular growth (Figure 3).

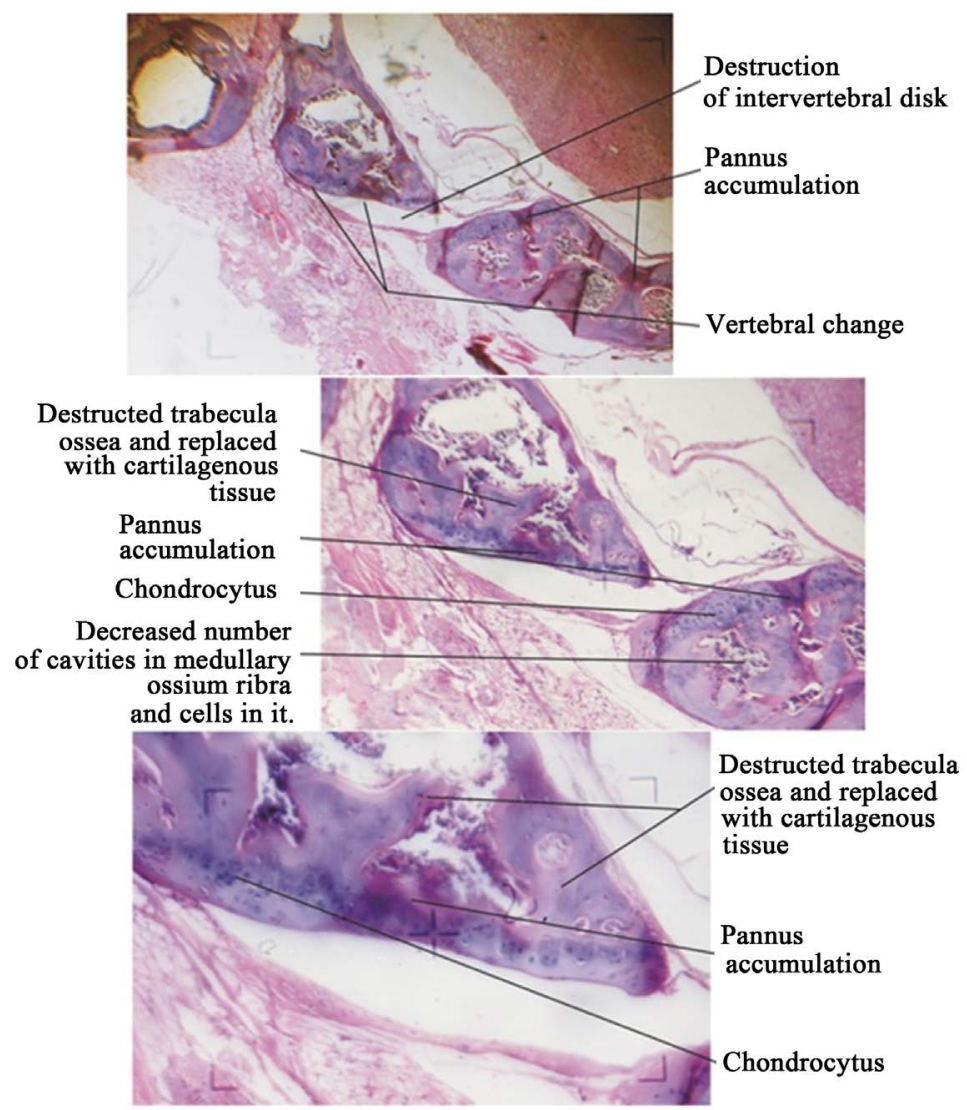

Figure 2. Intervertebral joint microstructure in the control group (after 56 days). Staining: Hematoxylin-eosin. Magnification at: $\mathrm{A} \times 40, \mathrm{~B} \times 100, \mathrm{~B} \times 200$. 


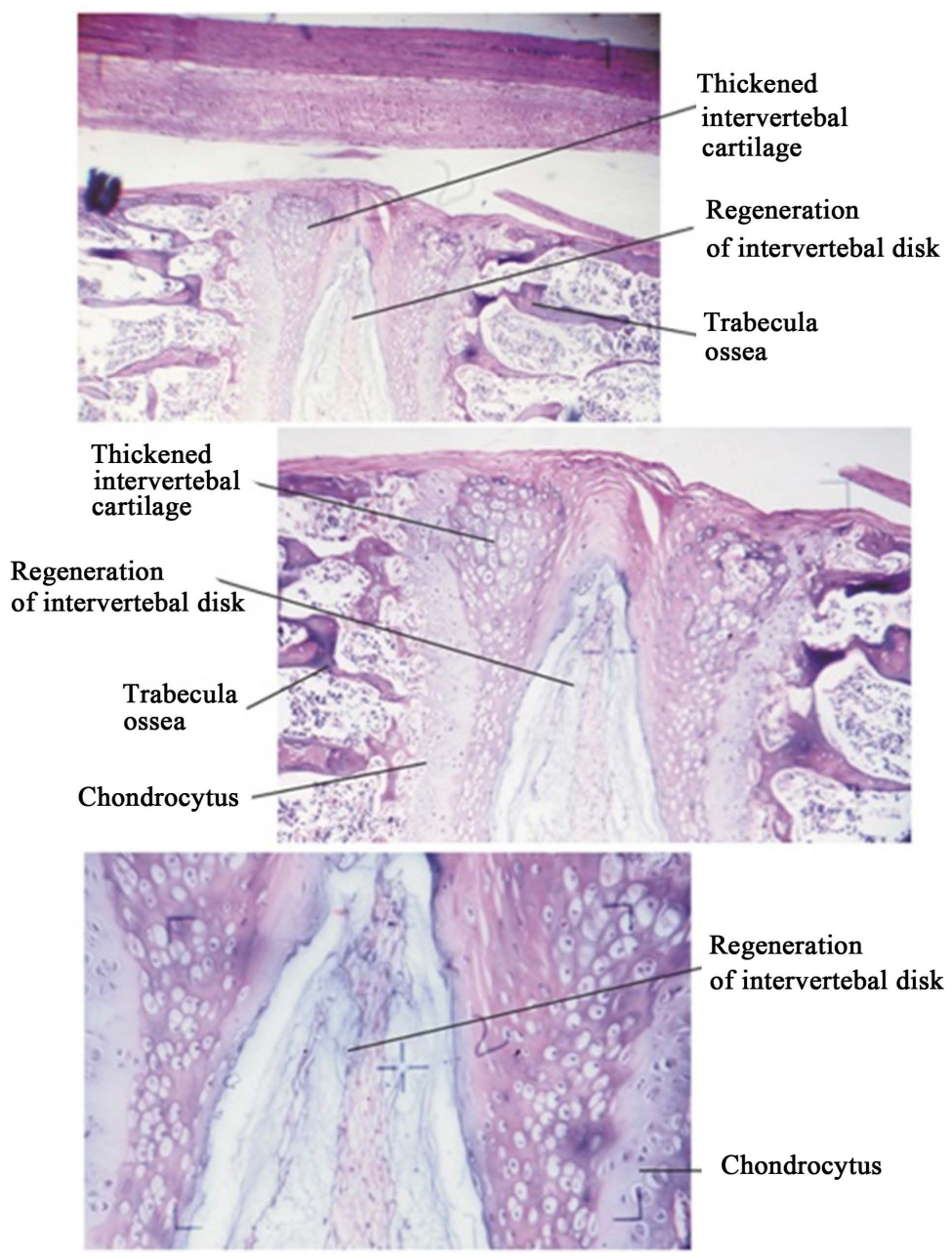

Figure 3. Intervertebral joint microstructure of mice in the Ibuprofen group. Staining: Hematoxylin-eosin. Magnification at: A ×40, Б ×100, B ×200.

\section{The Structural Changes on Intervertebral Disk after Ibuprofen Treatment}

The collagen fibers of intervertebral cartilaginous disk become sparse in mice induced with RA. Some cartilaginous disks of the vertebrae were destroyed and there was an empty space instead. When the nucleolus pulpous was cut, the cartilage discs were destroyed and had vanished. But the intervertebral disks of the mice that were treated with Ibuprofen were regenerated, the connective tissue cells and nucleolus pulpous deposition in the central part were surrounded by bundles of connective tissue fibers.

\section{Microstructural Changes on Vertebrae after Boigor-10 Treatment}

After Boigor-10 treatment, there was a decrease in pannus depositions and a damage on the surface of cartilage of the vertebral body. In addition, the Boigor-10 treatment intensified the regeneration process on vertebral body cartilages. When viewed through a microscope at $100 \times$ and $200 \times$ magnification, the perichondrium that covers adjacent vertebral body surfaces had thickened, and its chondroblastic cells shapes and the cytoplasmic acidification became normal (Figure 4). 


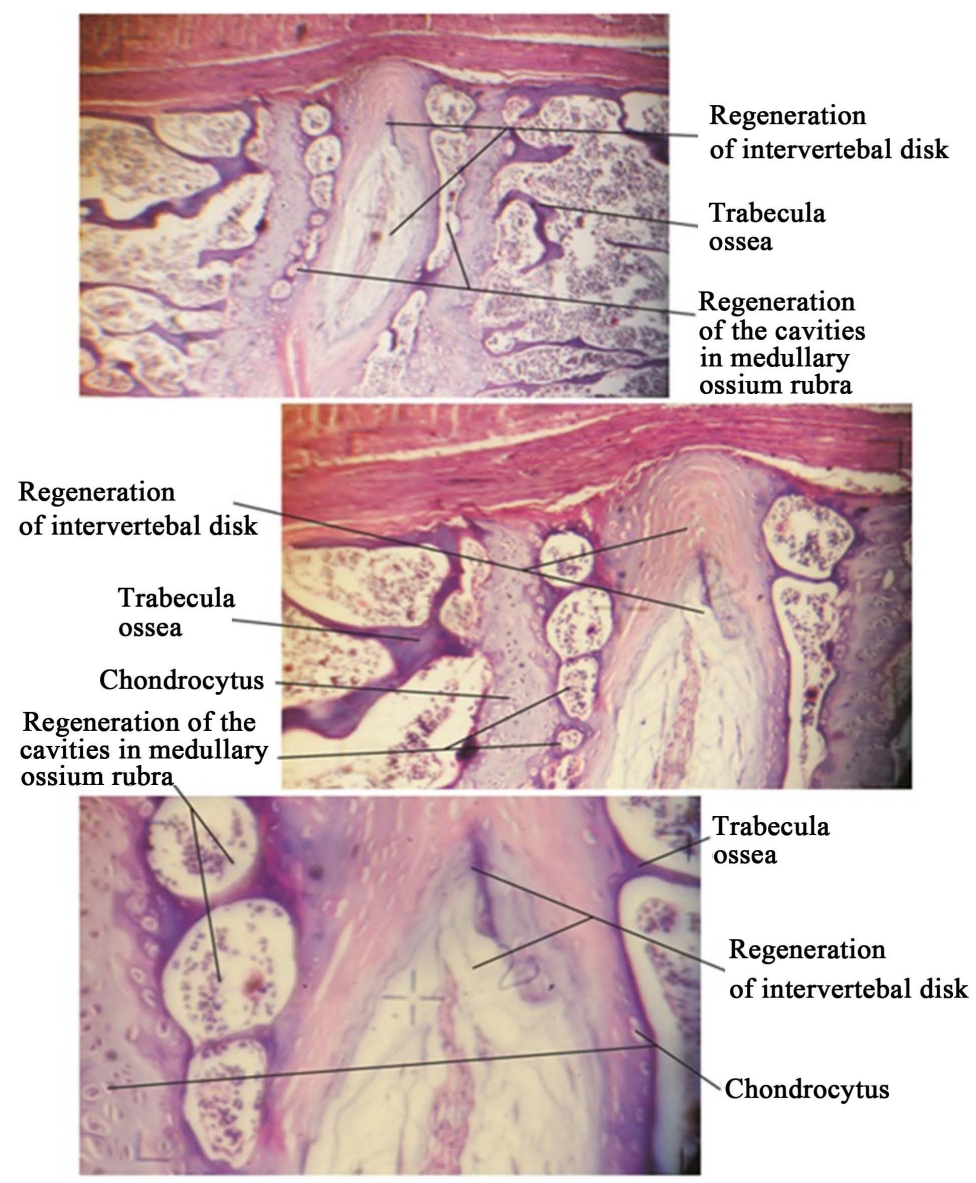

Figure 4. Intervertebral joint microstructure of mice in Boigor-10 Group. Staining: Hematoxylin-eosin. Magnification at: A ×40, $\mathrm{B} \times 100, \mathrm{~B} \times 200$.

\section{Structural Changes on Intervertebral Cartilaginous Disk after Boigor-10}

\section{Treatment}

The collagen fibers of Intervertebral cartilaginous disk become sparse in mice induced with RA. Some cartilaginous disks of the vertebrae were destroyed and there was an empty space instead. When the nucleous pulposus was cut, the cartilage discs were destroyed and had evaporated. But the intervertebral disks of the mice that were treated with Boigor-10 were regenerated, the connective tissue cells and nucleous pulposus deposition in the central part surrounded by bundles of connective tissue fibers were the same as the mice Group III who had ibuprofen treatment.

\section{Discussion}

For the collagen induced RA, we conducted our research according to the "Protocol for the Successful Induction of Collagen-Induced Arthritis (CIA) in Mice" by David D. Brand, Kary A. Latham, Edward F. Rosloniec published on $17^{\text {th }}$ May, 2007. On the first day of the experiment, we emulsified collagen II and Complete Freund's Adjuvant (CFA) with the ratio of 1:1 and injected $50 \mu \mathrm{l}$ volume intradermally in every mouse-tail. The experiment work protocols were 
written based on arthritis severity score system, body weight changes, and biopsy test results.

According to David D. Brand, Linda K. Myers (2002) study, the first symptoms of joint inflammation occurred on the $11^{\text {th }}$ day and clinical manifestations of arthritis appeared on the $35^{\text {th }}$ day [9].

According to the study of Edward F, Rosloniec (2007), in DBA/1 and most strain mice, the clinical manifestations of arthritis detected on day $18-21$ and arthritis incidence was $80 \%-100 \%$. As for Campbell (2000) experimental study, the arthritis clinical manifestation started after 3.5 weeks, the arthritis incidence occurred on week 6 - 8 and the severity scores reached 10 - 12 [5].

From the 21 st day to the $60^{\text {th }}$ day, Boigor-10 was given to the Group Ibuprofen and I was given to Group II orally. Arthritis was detected in all mice after 15 - 17 days of immunization of collagen II.

As for Collagen-induced RA study of G. Dariimaa and E. Bayarmaa (2011), the arthritis was detected in all mice from days 16 - 18 and the arthritis average severity score was 3.25 on the $16^{\text {th }}$ day, 4.03 on the $18^{\text {th }}$ day and 5.18 on the $20^{\text {th }}$ day respectively. In the study of collagen-induced RA of A. Pagmadulam, E. Bayarmaa (2012), detection of arthritis started from day $16-18^{\text {th }}$, the arthritis severity score in all mice was 3.25 on the $16^{\text {th }}$ day, 4.03 on the $18^{\text {th }}$ day and 5.18 on the $20^{\text {th }}$ day. Looking at the result of Collagen-induced RA study of G. Dariimaa and E. Bayarmaa (2011) and A. Pagmadulam, E. Bayarmaa (2012), we noticed that when comparing the experimental group mice which had collagen induced RA to the healthy group mice, the body weight increased by a little. Therefore, we concluded that all these study results were similar to this study.

The collagen induced experimental arthritis study (2013) of B. Hongorzul, E. Bayarmaa showed that from the first day through the $21^{\text {st }}$ day of the experiment, the body weight of healthy mice increased $(n=8)$ by 0.92 gr on average, while the control group mice body weight decreased by 2.15 gr. This result was possibly different due to the variety of methods that can be used with collagen-induced arthritis. Clinical manifestation results were similar to prior research results in Mongolia. We relate these findings to the breed or strain of the experimental animal.

According to the traditional medicine in Mongolia, the Influence of Traditional Medicine Senden-4 on Animal Model of Rheumatoid Arthritis [RA] study was carried out by researchers S. Soyolmaa, Z. Ariunaa and S. Oldokh. In this study, joint arthritis was induced by injecting $0.2 \mathrm{ml}$ solution of $4 \%$ papain and $0.1 \mathrm{ml}$ tsistein solution of $0.03 \mathrm{~m}$ in the $1^{\text {st }}, 4^{\text {th }}$ and $7^{\text {th }}$ weeks. The induced RA was treated by Traditional medicine Senden-4. The arthritis severity, histological examination and blood tests were taken and determined Senden- 4 traditional medicines action against inflammation.

We induced RA in mice treated with Boigor-10 and Ibuprofen and compared the result to the vertebral structure of the control group. After 56 days of immunization, pannus accumulation was formed on every vertebral surface, the number of cavities in medullary ossium rubra had decreased and the cells contained 
in it had also decreased dramatically. Trabeculs of the vertebral body had disappeared and were replaced with cartilage on the whole. After the treatments of Boigor-10 and Ibuprofen, the vertebral shapes became accurate, the pannus accumulation had disappeared, and the number of cavities in medullary ossium rubra and cells contained had increased. There was also an appearance of growing trabeculas in the vertebral body.

As for the results of collagen-induced RA study of G. Dariimaa and E. Bayarmaa (2011), Score 4 or the severity symptoms wasn't revealed. Infiltration of inflammatory cells in the cavities, the growth of connective tissue, and the joint surface cartilages had eroded by the pannus in joint biopsy test, which were similar to our results.

In the study results of Collagen-induced RA of A. Pagmadulam, E. Bayarmaa (2012), the joint biopsy test of the limbs on the $21^{\text {st }}$ day of the experimental, the synovial membrane had thickened greatly due to excessive proliferation. Therefore, it had infiltration in inflammatory tissues with lymphocytes, and pannus formation chondrocytes had developed, and joint surfaces had thickened. This conveys that we induced experimental model of RA successfully.

The collagen induced experimental arthritis study (2013) of B. Hongorzul, E. Bayarmaa showed that there was no changes in joint tissues of healthy mice in the biopsy test while the experimental group were treated with Derveger Jirgeruu and Sodium salicylate solution. The results in this study showed that the joint tissues had a score of 2.45 synovial membrane proliferation and formed cartilaginous tissue damages.

Shin-Yao Chen, Chao-Liang Wu study showed the following results, on the $16^{\text {th }}$ day of their experiment, the joint biopsy test score was 3, cartilage had formed and bone tissue was damaged, and inflammatory cells had infiltrated the bone [10]. Further results of Shin Yoshino study, conveys that on the $21^{\text {st }}$ day of biopsy test, showed changes in the arthritis severity score which scored 2.

In a pharmacological study on Mana-4 medicine carried out by Ch. Chimedragchaa (2002), they determined that Mana-4 forms and figures immune-regulation and inflammatory processes properly, strengthens cell membranes and antioxidants and intensifies cell regeneration [11]. Tsend-Ayush (1998) investigated Gurvan-Uriin Tan which had anti-clotting influence [12].

B. Uuganbayar (2013) conducted pharmacological study on Garid-5, (a traditional medicine) and identified its reactions against bacteria's such as: Staphylacocus aureus, Escherichai coli, Shigella dysenteriae, Pseudomonas aeruginasa, Proteus microbus, BaciIIus anthraci, Enterococc facialis, Klebsiella and Enterococcgallinarum, Escherichai coli bacteria which are resistant to many drugs [13]. These were similar to our findings.

\section{Conclusions}

1) The clinical manifestation score of experimentally induced RA increased to $2.37 \pm 0.10$ for the control group. Generated pannus deposition on cartilaginous disks of vertebrae destroyed the cartilage disks. 
2) The clinical manifestation score decreased to $1.63 \pm 0.11,1.58 \pm 0.11$ respectively, after Ibuprofen and Boigor-10 treatments of RA, decreasing the processes of cartilage damage and pannus deposition. It also intensified the regeneration of the vertebral cartilage.

\section{References}

[1] Jacobson D.L., Gange, S.J., Rose, N.R. and Graham, N.M. (1997) Epidemiology and Estimated Population Burden of Selected Autoimmune Diseases in the United States. Clinical Immunology and Immunopathology, 84, 223-243. https://doi.org/10.1006/clin.1997.4412

[2] Fairweather, D. and Rose, N.R. (2005) Women and Autoimmune Diseases. Emerging Infectious Diseases, 10, 204.

[3] Kong, Y., Sarosi, I., et al. (1999) Activated T Cells Regulate Bone Loss and Joint Destruction in Adjuvant Arthritis through Osteoprotegerin Ligand. Nature, 402, 304-309. https://doi.org/10.1038/35005552

[4] Seymour, H.E., Worsley, A., Smith, J.M. and Thomas, S.H.L. (2001) Anti-TNF Agents for Rheumatoid Arthritis. British Journal of Clinical Pharmacology, 51, 201-208.

[5] Brand, D.D., Latham, K.A. and Rosloniec, E.F. (2007) Collagen-Induced Arthritis. Nature Protocols, 2, 1269-1275. https://doi.org/10.1038/nprot.2007.173

[6] Lee, D. and Weinblatt, M. (2001) Rheumatoid Arthritis. Lancet, 358, 903-911. https://doi.org/10.1016/S0140-6736(01)06075-5

[7] Gregersen, P., et al. (1987) The Shared Epitope Hypothesis. An Approach to Understanding the Molecular Genetics of Susceptibility to Rheumatoid Arthritis. Arthritis \& Rheumatology, 30, 1205-1213.

[8] Budjav, L. (2000) Анагаах ухааны статистик судалгааны арга зүй, Улаанбаатар.

[9] Brand, D.D., Myers, L.K., Whittington, K.B., et al. (2002) Detection of Early Changes in Autoimmune $\mathrm{T}$ Cells Phenotype and Function Following Intravenous Administration of Type II Collagen in a TCR-Transgenic Model. Journal of Immunology, 168, 490-498. https://doi.org/10.4049/jimmunol.168.1.490

[10] Chen, S.Y., et al. (2011) Amelioration of Rat Collagen-Induced Arthritis through CD4+ T Cells Apoptosis and Synovial Interleukin-17 Reduction by Indoleamine 2,3-Dioxygenase Gene Therapy. Human Gene Therapy, 22, 145-154. https://doi.org/10.1089/hum.2009.217

[11] Chimedragchaa, Ch. (2002) Мана-4 тангийн фармакологийн судалгааны асуудалд Анагаах ухааны докторын зэрэг горилсон нэг сэдэвт бүтээл, Улаанбаатар.

[12] Tsend-Ayush, D. Гурван үрийн тангийн цусны бүлгийн зарим үзүүлэлтэнд үзүүлэх нөлөө. Анагаах ухааны магистрийн зэрэг горилсон бүтээл.

[13] Uuganbayar. В. (2013) Уламжлалт гарьд-5 жорын фармакологийн судалгааны зарим асуудалд Анагаах ухааны докторын зэрэг горилсон нэг сэдэвт бүтээл. Улаанбаатар. 